Original Research Paper

\title{
Sosialisasi dan Pelatihan Pembuatan Pupuk Organik Cair Berbasis Limbah Tanaman di Desa Ubung Kabupaten Lombok Tengah
}

\author{
Sukiman $^{1 *}$, Kurniasih Sukenti ${ }^{1}$, Nur Indah Julisaniah ${ }^{1}$, Rina Kurnianingsih ${ }^{1}$ \\ ${ }^{\text {I} P r o g r a m ~ S t u d i ~ B i o l o g i, ~ F a k u l t a s ~ M a t e m a t i k a ~ d a n ~ I l m u ~ P e n g e t a h u a n ~ A l a m, ~ U n i v e r s i t a s ~ M a t a r a m, ~ M a t a r a m, ~ I n d o n e s i a ~}$
}

https://doi.org/10.29303/jpmpi.v3i2.1117

Sitasi: Sukiman., Sukenti, K., Julisaniah, N. I \& Kurnianingsih, R. (2021). Sosialisasi dan Pelatihan Pembuatan Pupuk Organik Cair Berbasis Limbah Tanaman di Desa Ubung Kabupaten Lombok Tengah. Jurnal Pengabdian Magister Pendidikan IPA 4(4)

Article history

Received: 02 Oktober 2021

Revised: 20 Oktober 2021

Accepted: 07 November 2021

*Corresponding Author:

Sukiman, Program Studi Biologi, Fakultas Matematika dan Ilmu Pengetahuan Alam, Universitas Mataram, Mataram, Indonesia;

Email:

Sukiman1273@gmail.com

\begin{abstract}
Several problems related to the use of chemical fertilizers are fertilizer prices that continue to increase, in certain situations there is a shortage of fertilizers and continuous use can reduce the population of soil microorganisms. The purpose of this community service activity is to provide counseling and training on the manufacture of liquid organic fertilizer from plant waste using EM4 activator to the youth of Ubung Village, Jonggat District. The method of activity is lectures and practice of making liquid fertilizer, harvesting fertilizer products and packaging. The activity has been carried out in accordance with the plans and stages that have been set, and liquid fertilizer has been produced which is packaged in plastic bottles. The physical characteristics of the liquid fertilizer produced after 20 days of the fermentation process showed results that met the criteria as a good liquid organic fertilizer, namely temperature $28^{\circ} \mathrm{C}, \mathrm{pH} 4$, brownish yellow color and smelled of tape. Liquid fertilizer has been distributed to target residents and used as plant fertilizer. Through this activity, the youth of Ubung Village who are participants have succeeded in making liquid organic fertilizer based on plant waste and have applied it as fertilizer to their plants.
\end{abstract}

Keywords: Liquid fertilizer; Plant waste; Organic; EM4.

perkebunan. Desa Ubung juga direncanakan menjadi sentra penghasil buah-buahan di Lombok Tengah. Sebagian besar petani masih menggunkan pupuk kimia untuk menyuburkan lahan pertanian mereka. Beberapa permasalahan terkait penggunaan pupuk non organik yang dikeluhkan petani adalah harga pupuk yang terus meningkat dan pada situasi tertentu terjadi kelangkaan pupuk bersubsidi. Selain itu, menurut Riyanto et al., (2015) penggunaan bahan kimia pertanian secara terus-menerus dapat mengurangi populasi mikroorganisme yang berperan dalam daur biogeokimia tanah, serta mengurangi ketersediaan unsur hara.

Ketersediaan limbah organik di desa Ubung cukup melimpah yang berasal dari sampah rumah tangga, limbah ternak dan limbah pertanian. Masyarakat belum memanfaatkan secara maksimal potensi sampah organik yang ada dan belum ada 
upaya serius untuk mengolah dan memanfaatkannya. Padahal sampah-sampah organik tersebut masih bisa dimanfaatkan kembali untuk diolah menjadi pupuk organik. Berdasarkan potensi dan permasalahan yang dihadapi masyarakta di desa Ubung, maka perlu dilakukan penyuluhan dan pelatihan pembuatan Pupuk Organik Cair (POC) dari sampah organik (sayuran dan buah-buahan) yang banyak terdapat di desa tersebut.

Terdapat dua macam pupuk organik yaitu pupuk organik padat dan organik cair. Pupuk organik padat merupakan pupuk organik yang berasal dari sisa tanaman, kotoran hewan, dan kotoran manusia yang berbentuk padat sedangkan pupuk organik cair merupakan larutan yang berasal dari pembusukan bahan-bahan organik (Natsi et al. 2016). Pupuk organik cair merupakan pupuk organik dalam bentuk cair yang dibuat menggunakan proses fermentasi oleh mikroorganisme dan menggunakan bahan ataupun sampah organik. Pemakaian pupuk organik cair relatif lebih mudah dibandingkan pupuk organik padat karena dapat diberikan dengan penyemprotan atau penyiraman secara langsung pada tanah (Rachman et al. 2021).

Teknologi pembuatan pupuk organik cair telah dikembangkan dengan berbagai metode antara lain metode botol fermen, takakura, windraw dan metode lainnya. Sumber bahan baku pupuk organik tersedia dengan jumlah yang melimpah yang terutama dalam bentuk limbah, baik limbah rumah tangga, maupun limbah industri (Nasution et al., 2017). Pupuk organik lebih ramah lingkungan dan bisa dibuat sendiri oleh petani dari bahan - bahan yang tidak terpakai atau limbah yang banyak terdapat di desa, sehingga dapat mengurangi biaya produksi.

Pupuk organik dapat dibuat dari berbagai jenis bahan, antara lain sisa tanaman (jerami, brangkasan, tongkol jagung, bagas tebu, sabut kelapa), serbuk gergaji, kotoran hewan, limbah media jamur, limbah pasar, rumah tangga, dan pabrik serta pupuk hijau (Hartatik et al. 2015). Limbah sayur merupakan salah satu sumber bahan organik yang dapat dimanfaatkan untuk pembuatan POC karena mempunyai kelebihan mengandung hormon-hormon pertumbuhan tanaman (Nisa et al., 2014; Lestari et al., 2021), serta dapat meningkatkan mikroba tanah untuk memperbaiki struktur tanah meningkatkan penyerapan hara oleh akar tanaman, memperkuat akar dan meningkatkan daya tahan tanaman terhadap serangan hama dan penyakit, serta meningkatkan hasil tanaman (Fitriyatno et al., 2011). Limbah sayuran dapat dimanfaatkan menjadi pupuk organik cair (POC) karena mengandung banyak unsur hara makro maupun mikro (Indrajaya dan Suhartini, 2018). Peranan pupuk organik adalah sebagai sumber energi dan makanan bagi mikro dan meso fauna tanah. Dengan cukupnya tersedia bahan organik maka aktivitas organisme tanah meningkat yang juga meningkatkan ketersediaan hara, siklus hara tanah, dan pembentukan pori tanah (Hartatik et al. 2015). Selanjutnya Kasmawan et al. (2018) menambahkan bahwa beberapa manfaat pupuk organik bagi tanah adalah meningkatkan kesuburan tanah, memperbaiki struktur dan porositas tanah. Selain itu, pupuk organik juga dapat merangsang pertumbuhan mikroorganisme tanah yang menguntungkan bagi tanaman.

Tujuan kegiatan pengabdian pada masyarakat ini adalah untuk meningkatkan pengetahuan dan keterampilan pemuda desa Ubung dalam membuat pupuk organic cair berbasis limbah tanaman yang dilaksanakan melalui kegiatan sosialisasi dan pelatihan cara pembutan pupuk organic cair. Melalui kegiatan ini diharapkan petani bisa membuat pupuk organic sendiri dari bahan-bahan yang tersedia di desa tersebut.

\section{Metode}

Kegiatan pengadian pada masyarakat dilaksanakan melalui tahapan-tahapan sebagai berikut:

\section{Tahap Persiapan}

Tahapan persiapan meliputi: survey lokasi, persiapan alat dan bahan yang digunakan, perijinan dan koordinasi tim pelaksana dengan peserta sasaran.

2. Sosialisasi tentang pupuk organik cair yang dilakukan dengan penyebaran brosur dan pemaparan materi atau ceramah. Sosialisasi dilakukan untuk memberikan pemahaman mengenai pemanfaatan sampah organik dan cara pembuatan pupuk organik cair dari limbah tanaman.

3. Praktek pembuatan pupuk organik cair (POC). Peserta melakukan kegiatan praktik langsung pembuatan Pupuk Organik Cair (POC) yang dipandu oleh tim pelaksana pengabdian pada 
masyarakat. Mulai dari tahapan persiapan alat dan bahan, pengirisan bahan tanaman, pencampuran bahan, fermentasi, pemanenan dan pengemasan produk.

\section{Hasil dan Pembahasan}

\section{Pelaksanaan Kegiatan Pengabdian}

Sebelum pelaksanaan kegiatan pengabdian, terlebih dahulu dilakukan persiapan antara lain survei dan perizinan, sosialisasi awal kepada mitra. Desa ubung mempunyai lahan pertanian yang luas dengan ketersediaan limbah organik baik dari limbah ternak maupun tanaman yang cukup melimpah. Limbah organik tersebut sangat potensial sebagai bahan pembuatan pupuk organik.

Selanjutnya dilakukan kunjungan ke rumah kepala desa untuk menyampaikan tujuan dan rencana kegiatan pengabdian pada masyarakat yang akan dilaksanakan. Tim pengabdian kemudian mengadakan pertemuan dengan pemuda desa setempat yang akan menjadi mitra pada kegiatan pengabdian. Dari pertemuan tersebut disepakati jadwal, tempat dan pihak-pihak yang akan diundang pada kegiatan penyuluhan dan pelatihan pembuatan pupuk cair.

Kegiatan penyuluhan dan pelatihan pembuatan pupuk organik cair dilakukan pada hari Sabtu tanggal 4 September 2021 bertempat di kantor desa Ubung, Kecamatan Jonggat. Kegiatan ini dihadiri oleh 16 orang peserta yang terdiri dari pemuda-pemuda desa setempat. Kegiatan diawali dengan perkenalan dan penyampaian kata-kata sambutan oleh wakil tim pengabdian dan oleh peserta yang diwakili tokoh pemuda setempat. Selanjutnya dilakukan sosialisasi pembuatan pupuk organik cair oleh tim pengabdian. Sosialisasi dilakukan melalui pembagian brosur kepada peserta dan pemaparan materi penyuluhan tentang pupuk organik cair, cara pembuatan dan aplikasinya pada tanaman. Pada kegiatan sosialisasi tim pengabdian menjelaskan manfaat POC, cara pembuatan POC dan cara aplikasi POC pada tanaman.

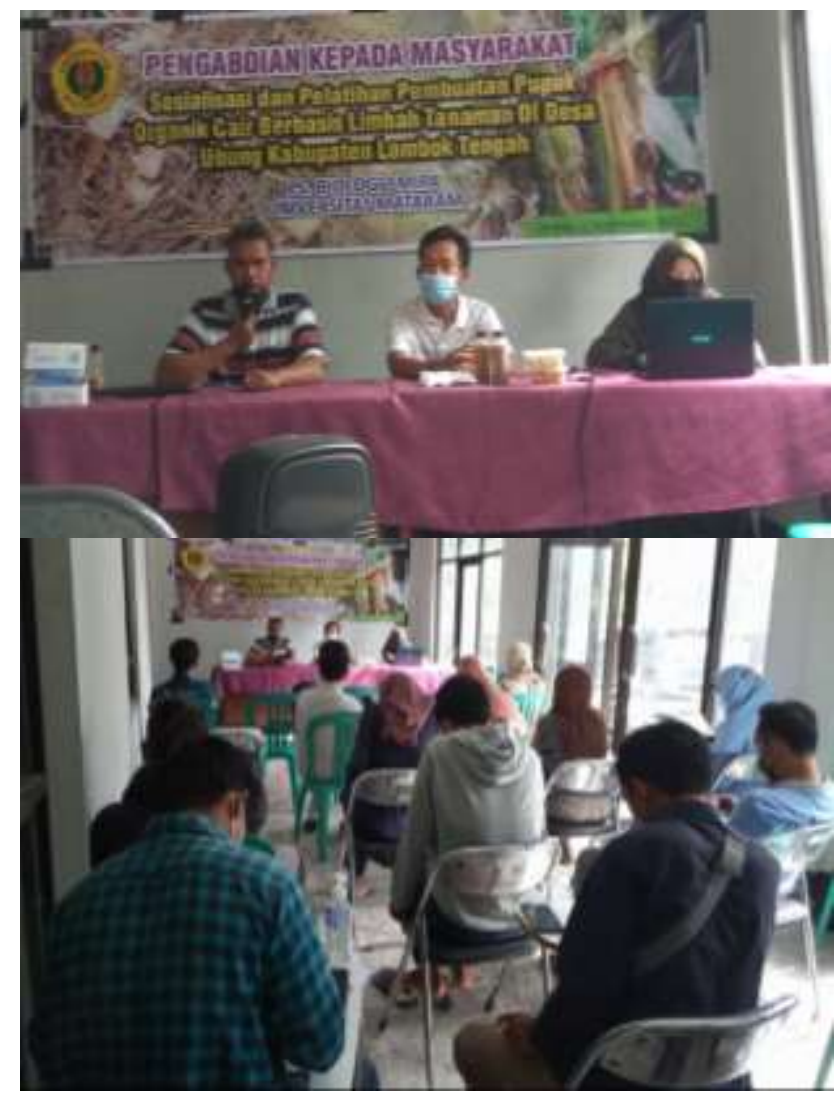

Gambar 1. Sosialisasi pembuatan pupuk organik cair di desa Ubung

Selanjutnya dilakukan praktek pembuatan pupuk organik cair yang dilakukan di halaman kantor desa. Ada dua cara yang dilakukan pada pembuatan pupuk cair ini yaitu pertama bahanbahan tanaman dihancurkan dengan cara diblender dan difermentasi menggunkan komposter yang terbuat dari jerigen berkapasitas 20 liter. Cara kedua bahan-bahan dicacah saja tanpa diblender dan difermentasi menggunakan komposter yang terbuat dari tong berkapasitas 40 liter. Cara pembuatan pembuatan POC yang pertama adalah sebagai berikut:

1. Pencacahan bahan-bahan tanaman yang digunakan yaitu batang pisang $5 \mathrm{~kg}$, limbah sayuran $5 \mathrm{~kg}$, dan limbah buah-buahan $3 \mathrm{~kg}$. Selanjutnya bahan-bahan tersebut diblender, lalu ditampung dalam ember.

2. Kemudian ditambahkan campuran larutan gula merah $1 / 4 \mathrm{~kg}$, EM4 $250 \mathrm{ml}$, terasi 50 gram dan air kelapa 5 liter. Bahan-bahan tersebut diaduk merata.

3. Bahan-bahan tersebut kemudian dimasukkan ke dalam komposter. Selanjutnya ditambahkan air 
sampai sampai volume bahan dalam komposter penuh, kemudian dilakukan proses fermentasi secara anaerob selama 20 hari.

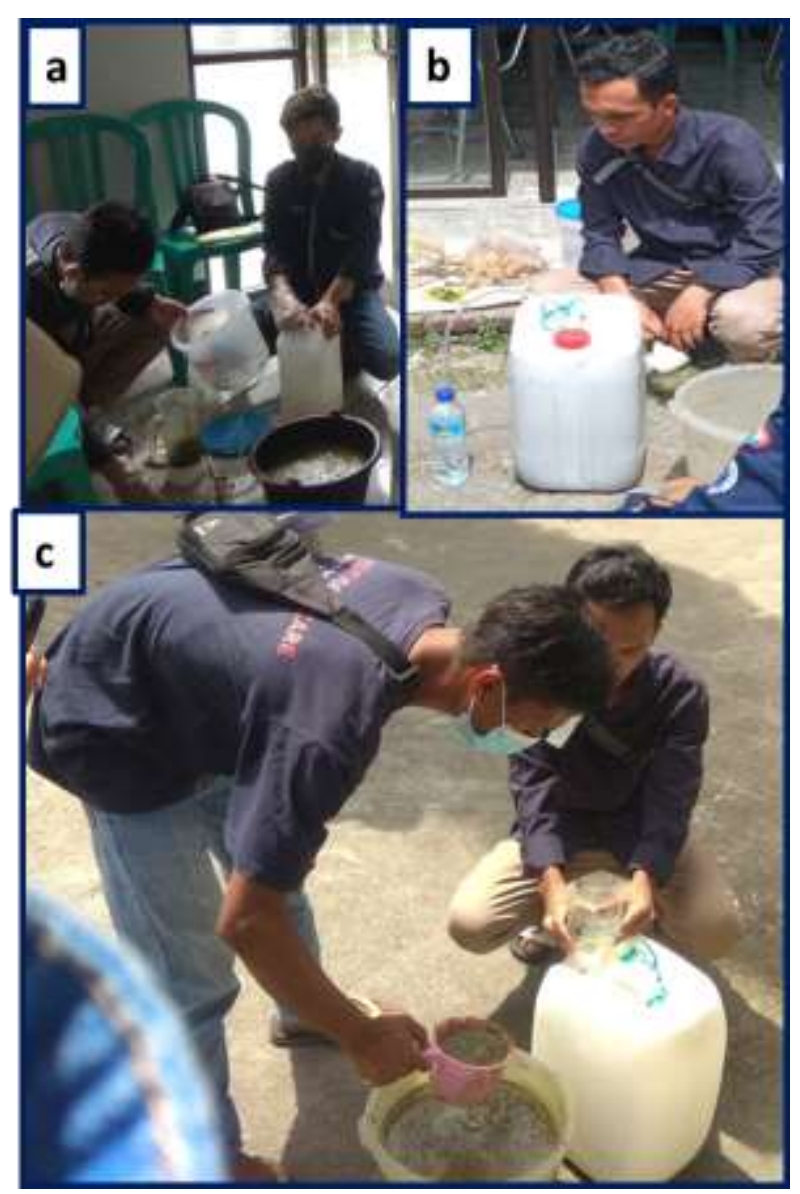

Gambar 2. Praktek pembuatan pupuk organik cair: a. penghancuran bahan, b. bahan siap difermentasi, c. memasukkan bahan ke dalam komposter

Selanjutnya praktek pembuatan pupuk cair yang kedua sebagai berikut:

1. Peserta melakukan pencacahan bahan-bahan tanaman yang sudah disipakan yaitu batang pisang $10 \mathrm{~kg}$, limbah sayuran dan hijauan $5 \mathrm{~kg}$, sabut kelapa $1 \frac{1}{2} \mathrm{~kg}$ dan limbah buah-buhan $10 \mathrm{~kg}$

2. Bahan-bahan tersebut kemudian dimasukkan ke dalam komposter dengan sabut kelapa paling bawah kemudian campuran cacahan limbah tanaman di atasnya.

3. Setelah itu peserta mencampur bahan-bahan tambahan yaitu larutan gula merah $1 / 2 \mathrm{~kg}$ dalam 5 liter air, 10 liter air kelapa, 1 botol EM 4, dan terasi yang dihaluskan 100 gram. Campuran tersebut diaduk merata kemudian ditambahkan ke dalam komposter, lalu di ditambahkan air sampai komposter terisi sekitar $90 \%$ volume.

4. Komposter ditutup rapat dan difermetasi selama 3 minggu secara anaerob. Setelah itu dilakukan pemanenan dan pengemasan pupuk dalam botol plastik dan jerigen.

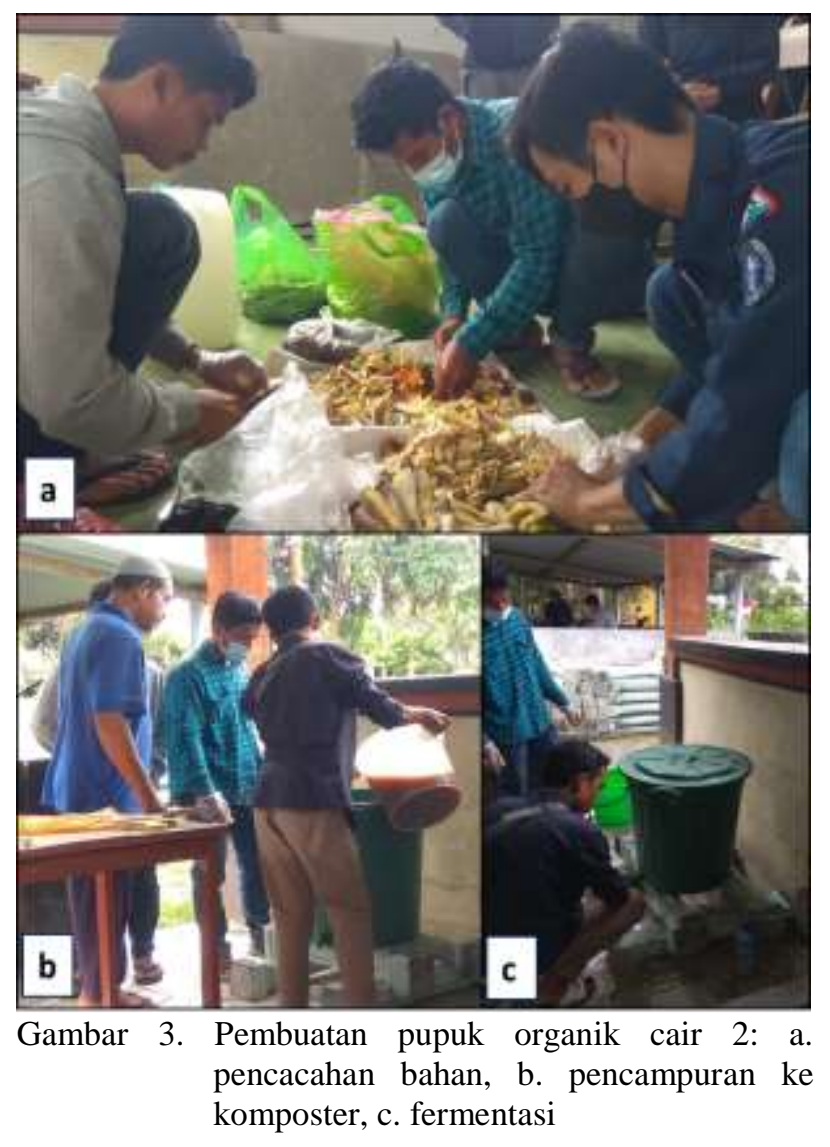

Pada pembuatan pupuk organik cair ini dilakukan penambahan air kelapa dan larutan gula merah. Dalam pembuatan pupuk organik cair perlu adanya penambahan cairan gula karena menurut Hadisuwito (2007), dengan penambahan gula dalam bentuk cair untuk membuat pupuk organik cair, maka mikroorganisme pengurai bahan organik akan dapat bekerja dengan maksimal. Hal ini dikarenakan gula mengandung glukosa sebagai sumber energi dari mikroorganisme. Adapun penambahan air kelapa berfungsi sebagai sumber mineral dan bahan-bahan organik. Kandungan mineral pada air kelapa berdasarkan data yang dirangkum oleh Prades et al. (2011) adalah K, Cl, $\mathrm{S}, \mathrm{Ca}, \mathrm{Na}, \mathrm{Mg}, \mathrm{P}, \mathrm{Mn}, \mathrm{Al}, \mathrm{Zn}, \mathrm{Fe}$, dan Cu. Selain itu juga air kelapa mempunyai kandungan bahan organik yaitu gula (sukrosa, fruktosa dan glukosa), protein, lemak, abu, dan vitamin B. Bahan organik 
sepertu gula menjadi sumber energi bagi mikroorganisme pengurai pada proses fermentasi. Sedangkan unsur mineral yang terkandung dalam air kelapa menjadi sumber hara bagi tanaman.

Proses fermentasi atau pengomposan limbah tanaman berfungsi untuk menguraikan bahan-bahan organik yang ada dalam limbah tersebut sehingga dapat diserap oleh tanaman. Untuk mempercepat proses fermentasi pada pembuatan POC ini ditambahkan EM4 sebagai bioaktivator yang mengandung mikroorganisme pemecah bahanbahan organik. Penambahan EM4 berfungsi untuk mengaktifkan bakteri pengurai bahan organik sehingga mampu menguraikan bahan organik menjadi zat hara yang mudah diserap oleh tanaman dalam waktu yang lebih cepat. Konsentrasi EM4 yang digunakan juga berpengaruh terhadap lama fermentasi, suhu, warna pupuk, dan aroma pupuk pupuk cair yang dihasilkan (Nasti et al. 2016).

Setelah difermentasi 20 hari, pupuk cair sudah bisa dipanen. Pupuk cair hasil fermentasi disaring kemudian cairan ditampung dalam ember, selanjutnya dikemas dalam botol plastik dan jerigen. Berdasarkan pengamatan aroma dan warna, pupuk yang dihasilkan dari pelatihan ini berwarna kuning kecoklatan dan beraroma tape, yang menandakan proses fermentasi berlangsung dengan sempurna. Pupuk cair tersebut sudah dapat digunakan sebagai pupuk tanaman.

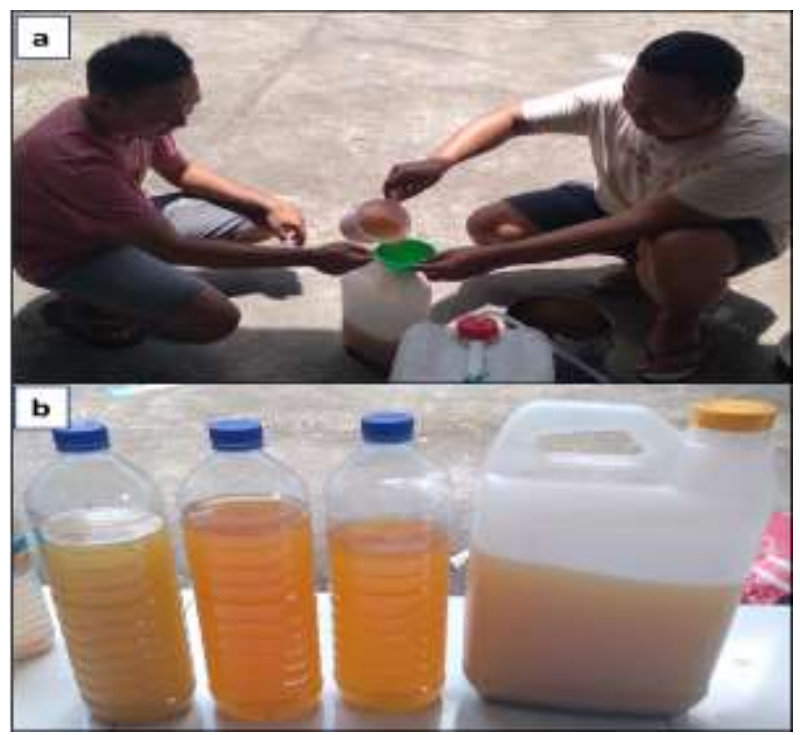

Gambar 4. Pemanenan pupuk cair: a. penyaringan, b. pupuk cair yang dihasilkan

Aplikasi pupuk cair dapat dilakukan dengan cara kocor atau menyiramkan pada area perakaran tanaman dengan takaran pupuk cair 1 liter dicampurkan dalam 10 liter air. Berdasarkan hasil wawancara dengan tokoh pemuda yang menjadi peserta kegiatan, semua pupuk cair hasil parktek pada kegiatan pengabdian sudah dipanen dan dibagikan kepada peserta dan warga setempat. Peserta sudah memanfaatkan pupuk cair tersebut untuk memupuk tanam jahe, jeruk dan tanaman budidaya lainnya. Menurut Hartatik et al. (2015), penggunaan pupuk organik sebaiknya harus dikombinasikan dengan pupuk anorganik dengan takaran yang lebih rendah. Apabila hanya menggunakan pupuk organik saja dikhawatirkan produktivitas tanah dan tanaman akan terus merosot, karena tanaman menguras hara dalam tanah tanpa pengembalian unsur hara dari pupuk yang memadai. Penggunaan pupuk organik dengan bahan yang sama terus-menerus juga akan menimbulkan ketidakseimbangan hara dalam tanah.

Kandungan unsur hara dan bahan organik pada pupuk organik dipengaruhi oleh beberapa faktor. Hasil penelitian Anggraini et al., (2019), menunjukkan bahwa susunan unsur hara (zat) yang dikandung oleh pupuk organik cair tergantung dari bahan dan cara pengomposan atau pembuatanya. Komposisi bahan tanaman yang digunakan juga berpengaruh terhadap kandungan unsur hara pupuk organik. Menurut Hartatik et al., (2015), komposisi hara dalam sisa tanaman sangat spesifik dan bervariasi, tergantung dari jenis tanaman. Sekam padi dan jerami mempunyai kandungan silika sangat tinggi namun berkadar nitrogen rendah. Sisa tanaman legum mengandung nitrogen cukup tinggi. Jerami padi, tandan kosong kelapa sawit, kentang, dan ubi jalar mengandung kalium yang tinggi. Selanjutnya menurut Kasmawan et al. (2018), untuk meningkatkan unsur nitrogen pada pupuk organik cair, perlu ditambahkan bahan organik berupa pupuk kandang dan tanaman legum (kacang-kacangan), untuk fosfor ditambahkan cacahan pisang atau batang pisang, sedangkan untuk kalium ditambahkan campuran bahan organik berupa batang pisang, kulit kentang, atau rumput laut.

\section{Ketercapaian Tujuan dan Manfaat Kegiatan}

Kegiatan pengabdian telah dilakukan sesuai dengan rencana yang sudah ditetapkan oleh tim pengabdian. Tahapan-tahapan kegiatan seperti penyiapan alat dan bahan, waktu dan tempat, koordinasi dengan peserta pelatihan, sampai 
tahapan sosialisasi sudah dilakukan sesuai jadwal yang sudah ditetapkan dan disepakati dengan warga sasaran.

Berdasarkan pemantauan dari tim pengabdian, peserta pelatihan sangat antusias dan terlibat secara aktif dalam kegiatan ini. Karena keterbatasan alat dan bahan, pada kegiatan praktek sebagian peserta secara langsung mempraktekkan cara pemubuatan pupuk cair secara bergiliran, sementara peserta lain mengikuti dan mencatat. Selama pelaksanaan kegiatan beberapa pertanyaan dari peserta yang hadir, di antaranya adalah terkait komposisi bahan yang digunakan, lama penyimpanan pupuk cair, aplikasinya untuk beberapa tanaman dan ada keinginan dari peserta untuk membuat pupuk cair untuk dijual ke petani.

Untuk mengetahui keberhasilan pembuatan pupuk cair, dalam hal ini dilakukan pengecekan terhadap sifat fisik pupuk yang dihasilkan yaitu $\mathrm{pH}$, suhu, warna, dan aroma. Hasil pengamatan kondisi fisik pupuk cair yang dihasilkan setelah 20 hari proses fermentasi memperlihatkan bahwa pupuk organik cair yang dibuat oleh peserta telah memenuhi kriteria sebagai pupuk organik cair yaitu suhu $28^{\circ} \mathrm{C}, \mathrm{pH}=4$, warna kuning kecoklatan dan beraroma tape. Hal ini sesuai dengan pendapat Rahman et al. (2017) bahwa ciri pupuk organik cair yang sudah terdekomposisi tidak berbau bususk dan memiliki bau seperti tape.

Ketercapaian tujuan kegiatan yang telah dilaksanakan dievaluasi berdasarkan perubahan pengetahuan dan ketrampilan yang dimiliki olah peserta dan sejauh mana produk POC yang dihasilkan dimanfaatkan oleh warga. Pada kegiatan ini peserta sudah dapat mempraktekkan pembuatan pupuk organik cair sesuai dengan prosedur yang ditetapkan. Proses fermentasi bahan organik juga berjalan dengan baik yang terlihat dari sifat fisik pupuk cair yang dihasilkan. Selanjutnya dari kegiatan ini dihasilkan produk yaitu pupuk organik cair yang dikemas dalam botol plastik dan jerigen dan sudah dibagikan kepada warga sasaran untuk dimanfaatakan sebagai pupuk untuk tanaman mereka. Dengan demikian kegiatan ini dapat dirasakan manfaatnya oleh warga. Nilai manfaat akan semakin bertambah jika pengetahuan dan keterampilan membuat pupuk cair disebarluaskan kepada warga lainnya dan diterapkan dalam usaha budidaya tanaman, hal inilah yang menjadi harapan tim pengabdian dan menjadi motivasi kepada warga.

\section{Dampak dan Upaya Keberlanjutan Kegiatan}

Dari hasil pelatihan yang sudah diikuti oleh peserta, mereka mendapat informasi dan pengetahuan baru tentang cara memanfaatkan sisasisa tanaman yang tidak dimanfaatkan. Selama ini banyak limbah tanaman dari limbah hasil pertanian, perkebunan dan limbah sayuran yang belum tidak dimanfaatkan. Dengan berbekal pengetahuan dan keterampilan yang diperoleh selama pelatihan, para peserta dapat mengolah dan memanfaatkan limbah tanaman tersebut menjadi pipuk organik cair. Hal ini dapat menjadi peluang bagi peserta untuk mengembangkan dan meningkatkan kreatifitasnya dalam memanfaatkan bahan-bahan yang ada di lingkungan sekitar yang memiliki nilai manfaat bagi kehidupan masyarakat, seperti penggunaan batang dan bonggol pisang, kulit buah-buahan, air dan sabut kelapa, dan limbah sayuran dari dapur sebagai bahan dasar pupuk cair. Hal ini merupakan salah satu solusi alternatif meningkatkan kandungan hara tanah yang dibutuhkan oleh tanaman selain penggunaan pupuk kimia yang selama ini harga relatif meningkat.

\section{Kesimpulan}

Kegiatan sosialisasi dan pelatihan pembuatan pupuk organik cair di desa Ubung telah terlaksana sesuai dengan rencana dan tahapan-tahapan yang sudah ditetapkan. Kegiatan ini memberikan dampak positif bagi pemuda desa, peserta kegiatan telah mengetahui cara pembuatan pupuk organik cair. Melalui kegiatan pengabdian ini, pemuda Desa Ubung berhasil membuat pupuk organik cair berbasis limbah tanaman. Hasil pengamatan kondisi fisik pupuk cair yang dihasilkan memenuhi kriteria sebagai pupuk organik cair yang baik. Produk yang dihasilkan dikemas dalam botol plastik dan telah dibagikan kepada warga untuk digunakan sebagi pupuk pada tanaman mereka. Kegiatan ini telah memberikan salah satu solusi alternatif untuk mengatasi masalah limbah organik dan semakin mahalnya pupuk kimia. Pelatihan ini perlu terus dilakukan guna meningkatkan pengetahuan, keterampilan dan kreativitas masyarakat secara luas untuk memproduksi kebutuhan sarana produksi pertanian secara mandiri, ramah lingkungan dan berdaya saing. 


\section{Ucapan Terima Kasih}

Penulis mengucapkan terima kasih kepada Lembaga Penelitian dan Pengabdian Masyarakat (LPPM) Universitas Mataram yang telah memfasilitasi kebutuhan dan kepentingan pengabdian ini, sehingga penulis dapat melaksanakan kegiatan pengabdian masyarakat ini di Desa Ubung, Kecamatan Jonggat Kabupaten Lombok Tengah.

\section{Daftar Pustaka}

Anggraini L., Kuswoyo V A., Marsya, M.A. 2019. Pembuatan Pupuk Organik Cair Dari Limbah Pasar Dengan Perbandingan Hasil Menggunakan Bioaktifator Air Tahu dan EM4. Jurnal Jaring SainTek Vol.1, No.1.

Erickson Sarjono Siboro, Edu Surya, Netti Herlina. 2013. Pembuatan Pupuk Cair Dan Biogas Dari Campuran Limbah Sayuran Jurnal Teknik Kimia USU, Vol. 2, No. 3 (2013).

Fitriyatno, Suparti, \& Anif, S. (2011). Uji Pupuk Organik Cair Dari Limbah Pasar Terhadap Pertumbuhan Tanaman Selada (Lactuca sativa L) Dengan Media Hidroponik. Prosiding Seminar Nasional IX Pendidikan Biologi FKIP UNS, 635641.

Hadisuwito, S. 2007. Membuat Pupuk Kompos Cair. Agromedia Pustaka. Jakarta.

Hartatik W., Husnain, Ladiyani R. Widowati 2015. Peranan Pupuk Organik Dalam Peningkatan Produktivitas Tanah Dan Tanaman Jurnal Sumberdaya Lahan Vol. 9 No. 2, Desember 2015; 107-12.

Kasmawan I.G.A., G.N. Sutapa, I.M. Yuliara. 2018. Pembuatan Pupuk Organik Cair Menggunakan Teknologi Komposting Sederhana. Buletin Udayana Mengabdi volume 17 NO. 02.

Lestari, A., Robbia, A. Z., Patech, L. R., \& Syukur, A. (2021). Optimalisasi Pemanfaatan Limbah Rumah Tangga sebagai Bahan Pupuk Organik Cair untuk Menumbuhkan Sikap dan Perilaku Peduli Lingkungan pada Siswa MTs. Haudhul Ulum Gegutu Telaga. Jurnal Pengabdian Magister Pendidikan IPA, 4(2).

Nasution. H, Henny D.J., Ulsanna Laira, Wahyuningsih. 2017. Pemanfaatan Limbah Cair Tahu Dan Daun Gamal (Gliricidia Sepium) Sebagai Pupuk Organik Cair Dengan Metoda
Fermentasi Dengan Aktivator Em4. Jurnal Photon Vol. 8 No. 1, Oktober 2017.

Natsi NA, Chaldun K., Salim. 2016 .Penerapan Teknologi Pembuatan Pupuk Organik Dalam Pengolahan Limbah Pasar Mardika Ambon. Biologi Sel. vol 5 no 1.

Nisa Robitul Mardliyah dan Yayok Suryo P.1 Pemanfaatan Unsur Makro (Npk) Limbah Cair Tahu Untuk Pembuatan Pupuk Cair Secara Aerobik. Jurnal Envirotek Vol. 9 No. 2.

Pardes A., Dorner M., Diop N., Pain JP. 2011. Coconut Water Use, Composition and Properties: Review. Fruits (vol (67): 2.

Rachman F , Erninda O., Maulana A , Fauzan ND , AnNajjah IS. 2021 .H2 super: inovasi pupuk organik cair dari sampah pasar H2, Desa Sido Mukti, Kecamatan Gedung Aji Baru Alturis Journal of Community service., Vol 2(1):4-7 DOI:10.22219/altruis.v2i1.159621.

Rinanto, Y. Sajidan, Umi Fatmawati. 2015. Pemanfaatan Limbah Sisa Hasil Panen Petani Sayuran di Boyolali sebagai Bahan Baku Pembuatan Pupuk Cair Organik menuju Pertanian Ramah Lingkungan. Prosiding Seminar Nasional Konservasi dan Pemanfaatan Sumber Daya Alam 2015.

Suhartini I. 2018. Uji Kualitas Dan Efektivitas Poc Dari Mol Limbah Sayuran Terhadap Pertumbuhan Dan Produktivitas Sawi. Jurnal Prodi Biologi Vol 7 No 8 Tahun 2018. 